\title{
TORTOR FUNCTION IN GONDANG NAPOSO BATAK TOBA COMMUNITY
}

\author{
Ruth Hertami Dyah Nugrahaningsih \\ Faculty of Language and Arts, State University of Medan, Psr. V Willem Iskandar St., Medan \\ Estate, North Sumatra 20222, Indonesia
}

\begin{abstract}
Tortor at the gondang naposo activity is one of the local charge dances of North Sumatra, which comes from the Toba Batak. Tortor is the term dance in the language of the Toba Batak region. In the Toba Batak community, tortor has a binding rule, sourced from the Dalihan $\mathrm{Na}$ Tolu kinship system, which describes roles in it such as Hula-hula, Boru, and Dongan Sabutuha. This article discusses the function of tortor. The theory used to explore its function is the theory put forward by Shay. The research method is qualitative descriptive. The results of the study concluded that tortor in Gondang Naposo activities fulfilled the six functions according to Shay, namely: dance as a reflection and legitimacy of social order, dance as a vehicle for secular and religious rites, dance as social or recreational entertainment, dance as a channel and release psychology, dance as a reflection of aesthetic value or an aesthetic activity in itself, and dance as a reflection of the pattern of economic activity as a support for life or economic activity in itself.
\end{abstract}

Keywords: tortor. gondang Naposo, function.

DOI: $10.7176 / \mathrm{JEP} / 10-2-19$

\section{Introduction}

The Batak tribe is divided into five sub-tribes. The Batak Toba sub-tribe is one of the sub-Bataks from the other four sub-tribes, namely: Batak Mandailing, Batak Karo, Batak Simalungun and Batak Pak-pak Dairi. In his life, the Batak Toba community upheld the implementation of their customs, guided by the applicable 'Dalihan Na Tolu' kinship system. This kinship system regulates the law that applies to the implementation of customary activities and relations between community members in life association. The kinship of the Toba Batak community is divided into two forms, namely 1) kinship based on lineage or geonology shown through clan and, 2) based on sociology formed through marriage.

The kinship system of the Batak Toba community, is an institution that binds relations between male relatives and female relatives. All parties included in the circle of relatives of the Batak Toba people, each of which has a name or designation that indicates his kinship status. The kinship system is Dalihan Na Tolu which consists of:

- $\quad$ Hula-hula, or a part called Parrajaon (the part being revised, the part giving the wife).

- $\quad B o r u$, is the part that accepts girls as wives

- $\quad$ Dongan Sabutuha or Dongan Tubu, namely all male off spring from one clan or from the same grandfather.

The function of the dalihan natolu in inter-clan social relations, is to regulate order and the way of speech implementation, determine the position, rights and obligations of a person and also as a basis for deliberation and consensus for the Batak Toba community. Wherever there are Batak Toba community, the dalihan natolu transfer function automatically applies. And as long as the Batak Toba people maintain societal awareness, as long as that is the function of the intermediate dalihan natolu, it is still considered good for regulating the procedures and living procedures of the community.

Gondang Naposo is an activity of young people of the Batak Toba community who aim to foster true social interaction among the younger generation, while still prioritizing rules or etiquette according to the prevailing kinship system. This activity is also a means for maturing attitudes and independence, in finding his soul mate following the Batak Toba customs. 


\section{Discussion}

The implementation of gondang naposo activities always includes seven tortors which are divided into three stages, namely:

a. Opening part (gondang parjolo)

1) Tortor Mula-mula.

This tortor became the beginning of open communication with the people who attended the Gondang Naposo activities. Gondang (song) used to accompany tortor was originally gondang mula-pertama. This Tortor is the starting point for the next purpose.

2) Tortor Somba.

Through tortor Somba, the role of suhut and the role of panatti convey his respect to

Debata Mulajadi Nabolon (the creator), to the customary King, and to the community.

Tortor is also a form of a panortor's request to the Dalihan $\mathrm{Na}$ Tolu elements and traditional leaders present to give their blessing.

3) Tortor Mangaliat is done while forming a circle and rotating three (3) times.

Showing an expectation that is believed to be granted, and everything that is

requested can be owned.

b. The contents (tortor parsaoran).

In this section, the manager may choose one of several tortors which are part of the contents, such as: tortor Si Bunga Jambu, tortor hatasopisik, or tortor monang- monang.

c. The third part is called the closing section.

Two forms of tortor will cover the entire series of gondang naposo activities, namely tortor

Hasahatan and tortor Sitio-tio. Tells about the attitude of gratitude for the blessings and health bestowed by Mulajadi Na Bolon, throughout the event, so that the program runs smoothly.

Anthony Shay (1971) explains there are six (6) categories of dance functions, namely: "1) dance as a reflection and legitimacy of the social order, 2) dance as a vehicle for secular and religious rites, 3) dance as social or recreational entertainment, 4) dance as a channel and psychological release, 5) dance as a reflection of aesthetic values or an aesthetic activity in itself, and 6) dance as a reflection of the pattern of economic activity as a support for life or economic activity in itself "(in Anya 2007: 85).

In accordance with Shay's theory above, it can be explained that the tortor of gondang naposo seems to fulfill the part as a reflection and legitimacy of the social order. The executor of tortor or called panortor, consists of two groups, namely: Suhut group (host) and panatti group (guest/invitation). Each group performs its function according to the predicate that is carried out. As the host, the Suhut group shows its responsibility by picking up panatti (guests) at the gate, and respectfully brings panatti into the arena where the activities are held. Another expression that embodies Shay's first function is the creation of mutual respect and respect without interfering with the rights and obligations of each role.

In the dance section serves as a vehicle for the expression of secular rites, tortor in gondang naposo stands as an activity held every year. This activity is an effort to instill a sense of love and belonging to the younger generation towards the traditional art of ancestral heritage, as well as introducing how moral messages must be realized and adhered to by young people in an era that is very powerful affecting the ethics of the younger generation.

Furthermore, the tortor show on gondang naposo is part of tourism activities, serves to provide entertainment or recreation to visitors and to the perpetrators. This activity has become a routine agenda of the local government of Samosir Regency. In this case, cultural preservation efforts are the most important part of being the goal of the Batak Toba community in its implementation. The simple dance movements but high artistic 
value make tortor in gondang naposo a fun dance.

In the dance function section as a channel and psychological release, it can be observed in the contents of the three stages of the implementation of tortor. In this section, the manager or dancer is given the freedom to express his youthful spirit, in his creativity to compose dance movements as a development of the existing traditional movements. In this section, all the abilities of the artistic creativity of young people in the Batak Toba community are expressed as an expression of their identity as a Batak tribe.

The function of dance is an aesthetic activity which is reflected in the activities of the manortor (dancing) illustrated when suhut and panatti's roles respond to each other in the tortor mangaliat part, to show the majesty of the customs of the Batak Toba people. It is seen how the role of the panatti (guest) gives satti- satti (souvenir) to suhut (host), as a sign of respect. Simple dance movements do not reduce the value of the deep beauty of tortor on gondang naposo.

The sixth function of Shay typology, which is dance as a reflection of the pattern of economic activity as a support for life or economic activity in itself, can be observed through the performance of the show. Being part of tourism activities, the gondang naposo program is also a place for the creative economy of the local community to take place. Tradition-based souvenirs and culinary are dynamic economic activities.

\section{Conclusion}

From the explanation of the function of the implementation of tortor in gondang naposo above, conclusions are drawn as follows:

1) As a reflection and legitimacy of the social order,

a. perpetrators tortor or called panortor (dancer), consists of two groups, namely:

Suhut group (host) and Panatti group (guest / invitation).

b. The creation of mutual respect and respect without interfering with the rights and obligations of each role.

2) As a vehicle for the expression of secular rites,

Tortor for gondang naposo is an activity held every year, as an effort to instill love and possess, as well as introduce how moral messages must be realized and obeyed by young people.

3) As a social or recreational entertainment,

The tortor and gondang naposo activities have become a routine agenda of the local government

of Samosir Regency, which serves to provide entertainment or recreation to visitors and to the perpetrators.

4) As a channel and psychological release,

Can be observed in the contents of the three stages of the implementation of tortor.

In this section, the manager or dancer is given the freedom to carry out the movement of dance to develop the movement of the existing tradition.

5) As a reflection of aesthetic value or an aesthetic activity in itself, it is illustrated the moment in which the role of Suhut and Panatti respond to each other in the tortor mangaliat section, to show the majesty of the customs of the Batak Toba people.

6) As a reflection of the pattern of economic activity as a support for life or economic activity in itself, it can be seen at the time of the performance. Gondang naposo event became the place for the creative economic activities of the local communityto take place.

\section{Reference}

Anya, Peterson Royce. 2007. Anthropology of Dance (trans. FX. Widaryanto). Bandung: Sunan Ambu Publisher Kluckhohn, F.R. and F.L. Strodtbeck. 1961. Variations in Value Orientaion: A Tasted Theory in Five Cultures. Evanston, Illinois. Row, Peterson and Co. 